\title{
THE IMPACT OF THE PROBLEM BASED TUTORIAL MODEL IMPLEMENTATION ON STUDENTS' ABILITY IN DESIGNING CLASSROOM ACTION RESEARCH AND WRITING A SCIENTIFIC REPORT
}

\author{
Tri Dyah Prastiti \\ tridyahprastiti@ut.ac.id \\ Sudilah \\ sudilah@ut.ac.id \\ Universitas Terbuka
}

\begin{abstract}
This paper is written based on the research done to the $6^{\text {th }}$ semester students of PGSD (Elementary School Teacher Training Program), Faculty of Teacher Training and Education (FKIP), Universitas Terbuka. The study aimed to describe the impact of the implementation of Problem Based Tutorial Model (PBTM) in Classroom Action Research (CAR) tutorial activities on the students' ability in designing CAR and writing a scientific report. The model is designed to help the students to implement the concept of CAR in their own teaching, and to make the report of the study in a well-written scientific writing. The model consists of Tutorial Activity Unit, Tutorial Design Activity, Student Worksheets and Evaluation Design. The results of study showed that after the implementation of the model the students were able to design a class room action research well. Each part of the report was written appropriately. Part I consists of introduction, part II (review of the related literature), and part III (results and discussion). The first study was done with students of PGSD at Magelang learning cluster. The average scores of the reports was 87 , whereas those done in Temanggung was 87,43 . This result showed the increase of the students' ability in writing a scientific report. Furthermore, the impact of the implementation of the model in Pokjar Temanggung showed higher scores than that of the previous implementation (in Pokjar Magelang) with the level of confidence $99 \%$.
\end{abstract}

Keywords: classroom section research, scientific report, problem based learning,

\section{Introduction}

At the $8^{\text {th }}$ semester, students of Elementary School Teachers Training (PGSD), Faculty of Education and Teacher Training (FKIP) UT, have to conduct a classroom action research (CAR) and write a scientific report as part of the tasks assigned for a required cource, named Professionalism Ability Reinforcement (PKP). 
At the $6^{\text {th }}$ semester, before taking PKP course, students are given the concept and design of how to do, and report the results of classroom action research. This course is ended with a class room action research proposal. Many students fail to fulfil this requirement because they haven't got experience of doing a research and writing the results of the study in a scientific report. Because of these reasons the researchers initiated to help students to implement the concept of CAR, and make a scientific report by using a model called Problem Based Tutorial Model (PBTM). This model was designed, based on the results of preveous studies which showed that most students have not been able to write the report of the study in a scientific way. Some important parts of the report were not appropriately written. They commonly occurred in writing: the back ground of the study, (2) the solution of the research problem, (3) the solutions do not refer to relvant theory, nor previous research results. To be a competent teacher, it is important that every teacher must be able to do CAR and make a scientific research report. It was by reasons of : (a) CAR can be used by teachers to improve classroom teaching and learning because the main target of the research is the improvement of learning, (b) teachers can grow professionally by doing the research, because it show that the teachers were able to assess and to improve classroom learning, (c) CAR make teachers more confident and (d) teachers got a chance to play an active role in developing their own knowledge and skills (Ward, et al., 2007: 1:19 - 1:24).

The students could create CAR reports if they had got conceptual knowledge of the CAR and practiced to make the reports. The conceptual knowledge is knowledge that is rich in relationships (Hudojo, 2005: 164). First, students need to acquire conceptual knowledge and then procedural knowledge (Krulik, et al., 2003: 7). Example of the conceptual knowledge on PKP subject is students relate CAR knowledge to problems often encountered with teacher in the classroom. Alternatively, students relate the activities carried out in CAR stages with the nature of the research. The nature is CAR as a systematic way to solve problems that occur in the classroom such that the condition become the expectation of the teacher.

Students who have conceptual knowledge are able to learn new information (Sutawidjaja \& Afgani, 2011: 3.21) and to solve problems in classroom or daily activities (Hudojo, 2005: 68). One of the methods that can encourage student to active in the classroom and give students experience in solving the problems is a Problem Based Learning (PBL) (Sutawidjaja and Afgani, 2011: 7.2). Problems can be questions given to students, whereby the students need to collaborate with his colleagues to answer. For example, students are given an example in chapter I of CAR report (scientific report). Based on the example, the tutor asked questions, for example: what is the main content of the background of the report? Students collaborate to determine the facts in the classroom or data that need to describe in the background of the report (chapter 1). Furthermore, students are given an example of a research problem. Based on it, the students solve the problems that are posed by tutor.

After having conceptual knowledge and practiced, students need to write chapters I (introduction), chapter II (review of related literature) and chapter III (results and discussion). Tutor can play role as an elementary teacher in classrom 
who take an action to improve teaching and learning. The students can act as elementary students or observer. On the next meeting, the elementary teacher, the elementary students and the observer are roled by the students. At the activities, the students and the tutor can obtain research data. The data can be used by tutors to make an example of chapter IV and V of CAR report.

Based on the previous description, the researcher conducted a study with research problem was "how did the effect of implementation of problem based and role playing tutorial model (PBRP) in tutorial activities which can help UT students to understand and have the ability to make scientific report? The report was related to the results of classroom action research.

\section{Material and Methods}

The type of the research was descriptive - comparative research. The researcher described the students' understanding of the theories and stages of CAR, activities and response of the students to the activities of PB tutorial model, and the students' ability to assemble chapters I, II and III of the scinetific report. Furthermore, the researcher also compared data of students' ability in writing the report between the current implementation results (in Pokjar Temanggung) and that of the previous implementation (in Pokjar Magelang).

The subjects were students of the 6th semester S1 PGSD Pokjar Temanggung UT Yogyakarta registration period 2015.1 which consists of 18 (eighteen) students. The research was done in Pokjar Temanggung, Yogyakarta. The research was conducted from January to August 2015.

The stages of the research were as follows.

1. The researcher applied the tutorial model PBTM in Pokjar Temanggung Yogyakarta. The model had previously been developed by the researcher in 2014 (Prastiti, 2014). The model consists of Tutorial Activity Unit, Tutorial Design Activity, Student Worksheet and Evaluation Design.

2. The researcher maked summary of observation result of student activities and student responses of the tutorial activities in tables.

4. The researcher described students' ability using statistical average, minimum and maximum.

5. The researcher compared data of students' ability of current implementation in Pokjar Temanggung with data of previous implementation in Pokjar Magelang.

\section{Result and Discussion}

Result

This research was a continuation of a previous study conducted by Prastiti and Suparti (2014). At the previous research, the researcher had developed a tutorial model of UPBJ] UT students in Pokjar Magelang Yogyakarta. Furthermore, the model was reimplemented in UPBJJ UT students in Pokjar Temanggung Yogyakarta. 
Based on the Tutorial Activity Unit in the model, the tutorial activities carried out by discussion group setting. In the tutorial 1-5 and 7, the students learn by using problem-based learning. In tutorial 6 and 8 , the students learn by using play a role.

In group discussion, the students solved problems in student's worksheets. The students' understanding of CAR appeared through students' answers that were written in student's worksheet. The nature of CAR is a teacher action to resolve problems that occured in the classroom. The students must be able to recognize the problem and identify the causes of the problems. At the first worksheet, tutor posed a real problem that occured at classroom to the students. Furthermore, the students were asked to identify the caused factors. The students' answers in first worksheet showed that the student had ability to recognize problems and identify its causes factors.

The students should have ability to determine the problem solution plan that based on the factors. The plan also based on relevant theories, teacher previous experiences, or previous research results. The students' answers in first worksheet showed that the students had ability to determine the problem solution plan based on the factors that caused the problems occur in the classroom.

Furthermore, the students should be able to define the research problem in accordance with the nature of CAR. If the students were able to determine the research problem, then they would also be able to formulate the objectives and the title of the research. Based on the students' answers in first worksheet, they had ability to determine the research problem in accordance with the nature of CAR.

Based on the steps of the tutorial model, tutor facilitated a class discussion such that these abilities could be internalized by the students to become a knowledge, and they were able to make chapter I of CAR report.

The students had ability to do the CAR if they could determine the activities in each stage of the research. The stages were (1) plan, (2) act, (3) observe, and (4) reflect. Based on the students' answers in second worksheet, they had an understanding of the stages of the research.

One of the important activities in order to be able to do CAR, the students should be able to make lesson plan in accordance with the solution plan that had been determined previously. Based on the students' answers in third and fourth worksheets, they had ability to make lesson plan 1 for cycle 1 (third worksheet) and lesson plan 2 for cycle 2 (fourth worksheet). The abilities to determine the stages of CAR and make the appropriate lesson plan were a key indicator of the ability to make chapter III of the research report.

The students' ability to perform CAR was also evident from the students' scores of tutorial tasks. On this research, there were three tasks in the evaluation design that had been developed earlier by the researcher. The task 1, 2 and 3 were make chapters I, II and III of the research report respectively. The summary of the task scores could be seen in Table 1. 
Ahmad Dahlan Journal of English Studies (ADJES)

Vol. 3, Issue 1, March 2016

Table 1. Scores of the Students in Implementing CAR

\begin{tabular}{lcccc}
\hline & TASK 1 & TASK 2 & TASK 3 & AVERAGE \\
\hline MINIMUM & 75 & 80 & 80 & 78,33 \\
MAKSIMUM & 95 & 90 & 95 & 90 \\
AVERAGE & 81,11 & 85,00 & 86,94 & 84,35 \\
\hline
\end{tabular}

The table indicates that, all students had been able to implement CAR. It appeared from the minimum score obtained by students (75). The scores also indicated that all students could write chapters I, II and III of the research report appropriately.

The students had an understanding of CAR and the ability to do the research because the tutorial model could encourage the students to learn actively in the tutorial. It generated a positive response/attitude towards the tutorial activities. The students who had a positive response will be able to understand the knowledge of the research, and had skills in applying the knowledge.

The data about the activeness of the students in this study was collected by using students' activities observation sheet. The results were presented in Table 2 below.

Table 2. Students' Activities in Participating tutorial

\begin{tabular}{|c|c|c|}
\hline NO & ACTIVITIES & PERCENTAGE \\
\hline & The Problem Based Learning & \\
\hline 1 & $\begin{array}{l}\text { Students read and understand a problem in the } \\
\text { worksheets. }\end{array}$ & $83,3 \%$ \\
\hline 2 & $\begin{array}{l}\text { Students discuss to determine the answers of the } \\
\text { problems }\end{array}$ & $83,3 \%$ \\
\hline 3 & $\begin{array}{l}\text { Students discuss actively to response the persentation } \\
\text { of other groups, ask, and answer or make a conclusion } \\
\text { in class discourse. }\end{array}$ & $77,8 \%$ \\
\hline
\end{tabular}

The table above shows the results of observation of the students' activities.It indicates that $77 \%$ of students are active during the tutorial. The activeness of the students in the tutorial is also shown by their positive responeses to the tutorial model. The data was collected by using questionnaires, and the results are presented in Table 3 below.

Table 3. Results of Students'Response

\begin{tabular}{llllccc}
\hline NO & \multicolumn{3}{c}{ STATEMENTS } & \multicolumn{4}{c}{ ASSESSMENT } \\
\cline { 3 - 6 } & & SD & DA & D & A & SA \\
\hline 1 & $\begin{array}{l}\text { You feel happy to learn with this tutorial } \\
\text { model (problem-based ). }\end{array}$ & $0 \%$ & $0 \%$ & $6 \%$ & $47 \%$ & $47 \%$ \\
2 & $\begin{array}{l}\text { Problem Based Tutorial Model can help me } \\
\text { understand the nature and the stages of } \\
\text { classroom action research that was }\end{array}$ & $9 \%$ & $9 \%$ & $59 \%$ & $21 \%$ \\
\hline
\end{tabular}

The Impact of the Problem Based Tutorial Model Implementation on Students' Ability in Designing Classroom Action Research and Writing a Scientific Report 


\begin{tabular}{|c|c|c|c|c|c|c|}
\hline \multirow[t]{2}{*}{ NO } & \multirow[t]{2}{*}{ STATEMENTS } & \multicolumn{5}{|c|}{ ASSESSMENT } \\
\hline & & SD & DA & D & $\mathbf{A}$ & SA \\
\hline & discussed & & & & & \\
\hline 3 & $\begin{array}{l}\text { You are motivated to learn the modules } \\
\text { independently by this tutorial model. }\end{array}$ & $0 \%$ & $3 \%$ & $16 \%$ & $69 \%$ & $12 \%$ \\
\hline 4 & $\begin{array}{l}\text { You are encouraged to solve the tasks } \\
\text { completely by this tutorial model. }\end{array}$ & $0 \%$ & $3 \%$ & $13 \%$ & $78 \%$ & $6 \%$ \\
\hline 5 & $\begin{array}{l}\text { You can understand how to write Part I, II } \\
\text { and III of the classroom action research } \\
\text { report better with this tutorial model. }\end{array}$ & $0 \%$ & $3 \%$ & $13 \%$ & $50 \%$ & $34 \%$ \\
\hline
\end{tabular}

Notes:

$\mathrm{SD}=$ Strongly Disagree, $\mathrm{DA}=$ Disagree, $\mathrm{D}=$ Doubtful, $\mathrm{A}=$ Agree, $\mathrm{SA}=$ Strongly Agree

Based on the table above, $84 \%$ of the students agree or strongly agree that the tutorial model fostered a joyful feeling in the learning, encouraged them to learn independently, help them to understand the concepts and the stages of CAR, and write Parts I, II and III of CAR report better.

The ability of the students in writing chapters I, II and III of CAR report was assessed using a rubric with indicators of each chapter seen as follows:

1. In chapter I, there were four elements assessed, namely the background of the problem, formulation of the problem, research objectives and benefits of the research. The maximum score of each element are respectively were 40, 20, 20 and 20.

2. In chapter II, there were two elements assessed, they are review of related literature and hypotheses. The maximum scores of each element are respectively were 80 and 20 .

3. In chapter III, there were two elements assessed, namely the research subject and the description of each CAR cycle. The maximum scores for each element are respectively 20 and 80 .

The results show that all students can write chapters I, II and III of CAR report better. Furthermore, the reports made by the students were assessed using a rubric that had been determined. The goal was to determine the level of students' ability in writing scientific report. Summary of the results for each elements after converted to a 100 scale could be seen in Table 4. It showed that the average score for each element had been over 70 . 
Ahmad Dahlan Journal of English Studies (ADJES)

Vol. 3, Issue 1, March 2016

Table 4. Assessment Result of Scientific Reports

\begin{tabular}{llllllllllll}
\hline NO & \multicolumn{4}{c}{ CHAPTER I } & \multicolumn{4}{c}{ CHAPTER II } & \multicolumn{3}{c}{ CHAPTER III } \\
\cline { 2 - 17 } & BI & FP & RO & RB & T- & RL & RH & 2 & SR & DC & 3- \\
\hline Minimum & 75 & 50 & 50 & 75 & 75 & 82 & 67 & 80 & 50 & 81 & 80 \\
Maksimum & 88 & 100 & 100 & 100 & 95 & 94 & 100 & 90 & 75 & 100 & 95 \\
Average & 82 & 74 & 72 & 96 & 81 & 86 & 78 & 85 & 71 & 91 & 87 \\
\hline
\end{tabular}

Notes:

$\mathrm{BI}=$ Background Issues; FP = Formulation of the Problem; RO = Research Objective;

$\mathrm{RB}=$ Research Benefits; $\mathrm{RL}=$ Review of Related Literature; $\mathrm{RH}=$ Research Hypotheses; SR = the Subject of Research; and DC = Description for each Cycle.

Title is also one of the main indicators in determining the quality of the research. Therefore, choice of words used in formulating the titles of the research should also be considered. The followings are examples of titles of the scientific reports submitted by the students.

The followings are some titles of scientific reports submitted by the students.

Table 5. The titles of Scientific Reports Proposed by the Students

\begin{tabular}{cll}
\hline No & $\begin{array}{l}\text { Student ID } \\
\text { Number }\end{array}$ & Title of the Students' CAR \\
\hline 1 & 823872786 & $\begin{array}{l}\text { Improving IPS Learning Achievement in History of Money } \\
\text { Using Inquiry Method with Coins and Banknotes on Grade }\end{array}$ \\
2 & 823872801 & $\begin{array}{l}\text { III Shekinah Christian Elementary, Temanggung } \\
\text { Improving Student Results of Science in Properties of Light } \\
\text { Using Inquiry Method with LCD projectors on Grade V SDN }\end{array}$ \\
3 & 823818205 & $\begin{array}{l}\text { 2 Tuksari Kalinegoro 6 } \\
\text { Improving Mathematical Achievement in Addition and } \\
\text { Multiplication Operations Using Jarimatika Method on Grade } \\
\text { II MI Tarbiyatul Athfal Pakurejo } \\
\text { The Efforts to Improve Mathematical Achievement in } \\
\text { Fraction Using CTL on Grade III SDN 2 Jombor. }\end{array}$ \\
\hline
\end{tabular}

As composition and rhetoric scholars, Maxine Hairston and Michael Keene explain that a good title does several things:

1. It predicts content.

2. It catches the reader's interest.

3. It reflects the tone or slant of the piece of writing.

4. It contains keywords that will make it easy to access by a computer search.

Keeping these functions in mind will help a writer choose a specific and meaningful title. 
Based on the hints given above, from the four examples can be stated that in a title there should be :

1. A learning problem which frequently occur in the classroom. From the four tittle above, there was a sentence "the efforts to improve mathematical achievement". The sentence implied the existence of a problem on student achievements in mathematics.

2. Spesific. In fourth title, the specific concept was fractions in third grade of elementary school.

3. A clear research subject. In fourth title, the research subject was third grade students in SDN 2 Jombor.

4. A method of solving the problems. In fourth title, the method was CTL (Contextual Teaching and Learning).

The students' ability to perform a CAR was also reflected at role playing activities in the sixth and eighth tutorial. One of the students act as an elementary teacher in implementing lesson plans in cycle 1 and 2. Four students act as observers and the others as elementary students. After role playing, the researcher asked the students to reflect on observation data by comparing it to indicators of successness that had been determined previously.

The current implementation of the tutorial model in UT students in Pokjar Temanggung Yogyakarta was a continuation and improvement of previous implementation in Pokjar Magelang Yogyakarta. Ineficiencies at the implementation in Pokjar Magelang were repaired and then reimplemented in Pokjar Temanggung. The implementation in Pokjar Temanggung was expected to improve ability of the students to do CAR and to make scientific report. In other words, tutorial scores of the students, that were relect their ability, in Pokjar Temanggung more than the scores in Pokjar Magelang. Therefore, the hypothesis for this comparison was:

$$
\begin{aligned}
& H_{0}: \mu_{\text {TEMANGGUNG }} \neq \mu_{\text {MAGELANG }} \\
& H_{1}: \mu_{\text {TEMANGGUNG }}>\mu_{\text {MAGELANG }}
\end{aligned}
$$

where $\mu_{\text {TEMANGGUNG }}=$ students ability in Pokjar Temanggung

$\mu_{M A G E L A N G}=$ students ability in Pokjar Magelang.

Descriptive statistics of the students' ability scores in both Pokjar as follows.

\section{Descriptive Statistics: TEMANGGUNG; MAGELANG}

$\begin{array}{llllllllll}\text { Variable } & \mathrm{N} & \mathrm{N}^{*} & \text { Meant } & \text { SE Meant StDev Minimum Q1 Median Q3 } \\ \text { TEMANGGUNG } & 18 & 0 & 87,430 & 0,823 & 3,491 & 81,233 & 84,708 & 87,700 & 90,667 \\ \text { MAGELANG } & 31 & 0 & 83,00 & 1,19 & 6,65 & 70,08 & 77,08 & 83,67 & 87,17\end{array}$

Variable Maximum

TEMANGGUNG 93,000

MAGELANG $\quad 94,17$

The difference of the average scores in Pokjar Temanggung and Magelang was 4.43. 
It meant that ability of the students in Pokjar Temanggung more than the students in Pokjar Magelang descriptively. Figure 1 shown that the boxplots of Pokjar Temanggung above Pokjar Magelang.

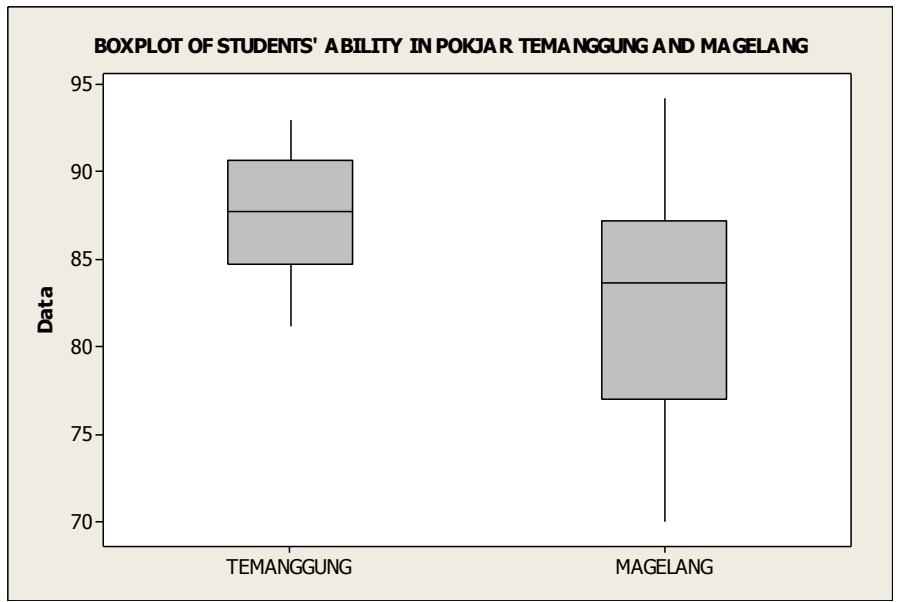

Figure 1 Boxplot of Students' Ability in Pokjar Temanggung and Magelang

The significance of the result would be further tested using statistical test. The researcher conducted a normality test by using Kolmogorov-Smirnov before performing the test.

The normality test result of the data students' ability in Pokjar Temanggung was $p$-value $>0.1$ with $a=1 \%=0.01$, then the $p$-value $>a$. It meant the data of the students ability in Pokjar Temanggung has normal distribution. Furthermore, the p-value of the data of the students' ability in Pokjar Magelang was 0.048. It was also more than $a=1 \%=0.01$. It was indicated that data of students' ability in Pokjar Magelang has normal distribution. Next, the researcher examined the homogeneity of variance between the two data of students' abilities. The test used F-test. The result using Minitab 16.2.1 was as follows.

\section{Test and CI for Two Variances: TEMANGGUNG; MAGELANG}

Method

Null hypothesis Sigma(TEMANGGUNG) $/$ Sigma $($ MAGELANG $)=1$

Alternative hypothesis Sigma(TEMANGGUNG) / Sigma(MAGELANG) not $=1$

Significance level Alpha $=0,05$

Statistics

Variable N StDev Variance

TEMANGGUNG $\quad 18 \quad 3,491 \quad 12,190$

MAGELANG $\quad 316,650 \quad 44,218$

Ratio of standard deviations $=0,525$

The Impact of the Problem Based Tutorial Model Implementation on Students' Ability in

Designing Classroom Action Research and Writing a Scientific Report 
Ratio of variances $=0,276$

$95 \%$ Confidence Intervals

CI for

Distribution CI for StDev Variance

of Data Ratio Ratio

Normal $\quad(0,350 ; 0,831)(0,122 ; 0,690)$

Continuous $(0,341 ; 0,717)(0,117 ; 0,514)$

Tests

Test

Method DF1 DF2 Statistic P-Value

$\begin{array}{lllll}\text { F Test (normal) } & 17 & 30 & 0,28 & 0,007\end{array}$

Levene's Test (any continuous) $\quad \begin{array}{llll}1 & 47 & 12,30 & 0,001\end{array}$

The result was $p$-value $=0,007<a=0.01=1 \%$. It meant the data was not homogeneous variances.

Based on the result of homogeneity of variance test, the researcher used ttest of two samples comparison with unhomogenous variance. The result of the test using Minitab 16.2.1 was as follows.

\section{Two-Sample T-Test and CI: TEMANGGUNG; MAGELANG}

Two-sample T for TEMANGGUNG vs MAGELANG

$\begin{array}{lrllc} & N & \text { Meant } & \text { StDev } & \text { SE Meant } \\ \text { TEMANGGUNG } & 18 & 87,43 & 3,49 & 0,82 \\ \text { MAGELANG } & 31 & 83,00 & 6,65 & 1,2\end{array}$

Difference $=\mathrm{mu}($ TEMANGGUNG) $-\mathrm{mu}($ MAGELANG)

Estimate for difference: 4,43

95\% lower bound for difference: 1,99

T-Test of difference $=0$ (vs >): T-Value $=3,05$ P-Value $=0,002 \quad$ DF $=46$

The t-test result was $\mathrm{p}$-value $=0,002<\mathrm{a}=0.01=1 \%$. The conclusion was rejected $H_{0}$ with a significance level $99 \%$, which meant the students' ability in Pokjar Temanggung more than in Pokjar Magelang significantly. Thus, there was a very significant increase in the ability of the students at the current implementation of the tutorial model in Pokjar Temanggung than previously implementation in Pokjar Magelang.

The ability of the students in making chapters I, II and III of CAR report was assessed using a rubric with indicators for each chapter as follows.

1. In chapter I, there were four elements be assessed namely the background of the problem, formulation of the problem, research objectives and benefits of the 
Ahmad Dahlan Journal of English Studies (ADJES)

Vol. 3, Issue 1, March 2016

research. The maximum scores of each element respectively were 40, 20, 20 and 20.

2. In chapter II, there were two elements be assessed, namely a literature review and hypotheses. The maximum scores of each element respectively were 80 and 20.

3. In chapter III, there were two elements be assessed, namely the research subject and a description for each CAR cycle. The maximum scores for each element respectively were 20 and 80 .

The result showed that all students can make chapters I, II and III of CAR report. Furthermore, the reports made by the students were assessed using a rubric that had been determined. The goal was to determine the level of students' ability in making the report. Summary of the result for each elements after be converted to a scale 100 could be seen in Table 4.

\section{Discussion}

The first objective of the research is to know the impact of the implement of the Problem Based Tutorial Model on the tutorial activities which could help students to understand the concept of CAR and have the ability to do the reseach. The implementation result showed that the students had the ability:

a. to recognize the existence of learning problems that occur in the classroom and identifying the causes factors,

b. to make a solution plan of the problems,

c. to determine the problem research that satifisy the nature of CAR,

d. to determine the research objective and research title that were relevant to the research problem,

e. to describe the activities performed at each stage of the research,

f. to make lesson plans of cycles 1 and 2,

g. to implemente the lesson plans in a playing role.

Thus, the Problem Based tutorial model could help the students to achieve these objectives.

The implementation result also showed that at least $77 \%$ of the students were active in (a) reading and understanding the problem in the worksheets, (b) cooperating to solve the problems in group discussion, (c) asking or answering to response the other group presentation in class discussion, (d) making a conclusion and (d) playing role as a teacher, a student, or an observer. It showed that the model was able to encourage student to learn actively in the tutorial.

The second objective of this study was to help the students have the ability to make scientific report. The result showed that all the students can make the report. The research titles had also been in accordance with the nature of CAR, namely (a) contains implicitly the problems that occur in the classroom, (b) contains a research subject clearly, (c) contains a specific mathematical concept, and (d) contains a method of solving the problems. In addition, the average scores of the research proposal that had beed made by the students was more than 70 . It also indicated that the students had ability to make a scientific report. 
The model implementation was carry out in eight tutorials where at the tutorials 1 to 5, the students learned about the nature, the steps of CAR, design chapters I, II, III of scientific report, and draw up lesson plans 1 . At the sixth tutorial, the students played role to implement lesson plan 1 dan maked a reflection. At the tutorial seventh, the students implemented lesson plan 2 and maked reflection. In the eighth tutorial, the students learned to make scientific report. It meant PBRP tutorial model could be implemented in eight tutorial that satisfied the plan that had been developed previously. This study was a continuation of a study conducted by the researcher previously (Prastiti, 2014).

In the previous study, the researcher had developed a draft model of the tutorial model. The draft had beed implemented in small groups of students in UPBJ] UT Pokjar Magelang Yogyakarta. Based on the implementation, the researcher revised the draft. The revising draft were used in this study. In addition, this study used the assessment rubric of chapters I, II, III of CAR report which was not used in previous study. Therefore, this study was the improvement in both the design and implementation from previous research.

The result also showed an increase students' understanding of the CAR from the previous one. In the previous study, the average score of the tutorial was 78.65 (Prastiti, 2014: 30) increased by $7.3 \%$ to 84.35 (scale of 100) in this study. Furthermore, the result also showed that the average score for each indicator chapters I, II and III of the report was more than 70. It showed that the students have the ability to make scientific report of CAR from chapter I to III. In addition, the activity level of students also increased from 71\% (Prastiti, 2014: 29) in an previous study increased by $8,5 \%$ to $77 \%$ in this study.

In general, the implementation in Pokjar Temanggung was better than that in Pokjar Magelang. It was demonstrated by the students' ability in Pokjar Temanggung was more than Pokjar Magelang very significantly with an error rate was $1 \%$.

\section{Conclusions and Suggestions}

\section{Conclusions}

The result showed that the students had the ability to do the classsroom action research. It appeared from the students ability in identifying learning problems that occur in the classroom and identify caused factors, could make a plan for solving problems, could determine the research problem in accordance with the nature of classroom action research, could determine the purpose and the title of research corresponding to the research problem, could describe the activities performed at each stage of the research, could devise lessson plan cycles 1 and 2, and could implement the lesson plan in playing role.

The result also showed that students were able to make chapters I, II and III of scientific report where the title had satifisfied the nature of classroom action research. The ability was also indicated by the average scores of the report for each indicator of chapters I, II and II were more than 70. 
Implementation in Pokjar (learning cluster) Temanggung showed improved results compared with the implementation in Pokjar Magelang. Average scores of the ablitiy of the students in Pokjar Temanggung and Pokjar Magelang respectively were 87.43 and 83 . The result of statistical culculation using t-test comparison of two samples was: $p$-value $=0,002<a=0.01=1 \%$. Therefore, the students' ablitiy in making scientific report in Pokjar Temanggung is greater than in Pokjar Magelang very significantly with an error rate was $1 \%$.

\section{Suggestion}

Some suggestions were given by the researcher to tutors who will use this model should pay attention to the group discussion. Tutor should get around to all the groups and ask students' progress in answering questions related to the problems in the worksheets. If there were students who were experience difficulties, tutors should give scaffolding by asking the students to understand the problems discussed in the worksheets or by asking metacognitive questions that could assist students in finding the answers. At discussion of first worksheet, tutors should facilitate students in making plans to solve the problems based on the theory of constructivism, teacher's previous experiences, or the results of previous researchs. In addition, tutor should also facilitate students in determining the research problem in accordance with the nature of CAR. At discussion of worsheet 2, tutors should facilitate students to prepare lesson plans in accordance with the theory of constructivism and solustion plans that have been made previously. At applying lesson plans 1 and 2 (playing role), the tutor should facilitate the fourth stage of class action research, namely reflection. It was done by comparing the data that was obeserved by the students to the indicators of success that has been predetermined.

\section{BIBLIOGRAPHY}

Hairston, Maxine, and Michael Keene. 2003. Successful Writing.5th ed.

New York: Norton

Hudojo, H. 2005. Kapita Selekta Pembelajaran Matematika. Malang: Universitas Negeri Malang.

Krulik, S., et. al. 2003. Teaching Mathematics in Middle Schools. A Practical Guide. Boston: Pearson Education Inc.

Prastiti, Tri Dyah et. al. 2014. Pengembangan Model Tutorial Berbasis Masalah dan Bermain Peran untuk Peningkatan Pemahaman Penelitian Tindakan Kelas pada Mahasiswa Universitas Terbuka. Research Result, unpublished, Universitas Terbuka.

Sutawidjaja, A. and Afgani, J. D. 2011. Pembelajaran Matematika. Jakarta: Penerbit Universitas Terbuka.

Wardhani, IGAK, et. al. 2007. Penelitian Tindakan Kelas. Jakarta: Penerbit Universitas Terbuka. 2015. General Format for Writing a Scientific Paper

http://www.instruction.greenriver.edu/mcvay/b100/general_format_for_writi ng_a_sci.htm 